\title{
“iSOMOS MÁS AMERICANOS!": The music of Los Tigres del Norte as Grass Roots Activism
}

\author{
Transforming Cultures eJournal, \\ Vol. 4 No 1 April 2009 \\ http://epress.lib.uts.edu.au/journals/TfC
}

Mariana Rodriguez ${ }^{1}$

\section{Abstract}

The music of popular Mexican band Los Tigres del Norte illustrates a Mexican migrant and Chicano/a tradition of using popular music as an alternative way of narrating community life in the U.S.A., most notably the Mexican migrant, Chicana/o and Mexican-American experience of discrimination along ethnic, class, gender and cultural lines. The band grapples with the ways by which a dominant U.S. national discourse has historically subordinated Mexican migrant and Chicano/a communities. Through their lyrics they propose a kind of progressive politics that underscores the importance of equality and antidiscrimination based on ethnic, cultural, gender and class positions. I believe that Los Tigres del Norte should be regarded as political activists, using their lyrics and musical profile to articulate and present a kind of progressive politics on behalf of Mexican migrants and Chicanos, and in ways that work with the legacies of the Chicano Movement in the 1960s and 1970s. Los Tigres del Norte are worthy of attention for a number of reasons. First, they speak of the importance of community building as a form of empowerment for immigrant groups and ethnic minorities in the U.S.A., as typified by the long tradition of community organizations among Mexican migrants, Chicanas/os and MexicanAmerican communities. Second, it is arguable that Los Tigres del Norte continue the Chicano/a movement fight for human rights and equality. Los Tigres del Norte claim a place for Mexican migrants and Chicanos/as as a viable and productive constituency within the U.S.A. Third, while these musicians are male performers, who engage with civil and migrant rights, they also deal with female issues and characters, departing from traditional views and ideals of the subordinate role of women in Mexican migrant and Chicana/o patriarchal societies. Los Tigres del Norte also engage with notions of an 'America' whose pan-ethnic qualities mark the importance of alliances between diverse groups. Their focus on the immigrant experience -documented and undocumentedmakes their music an important example of a political project of pan-Latino and pan-American affiliation. In this way, I argue that Los Tigres del Norte should be regarded not only as 'the most famous and popular band in contemporary Mexican culture band' (Wald 2001) but as political activists who, in their lyrics, articulate political and social issues affecting the Mexican migrant and

\footnotetext{
${ }^{1}$ Is a PhD candidate at the University of Technology, Sydney.
} 
Chicana/o communities which might be read as legacies of the Chicano Movement in the 1960s and 1970s.

\section{Introduction}

This paper seeks to demonstrate Los Tigres del Norte's use of popular music as an alternative form of expression to narrate their community's experience of discrimination in the U.S.A.

In their music Los Tigres del Norte tackle the way in which the Mexican American, Mexican migrant and Chicano/a communities have been historically subordinated by the dominant U.S. national discourse. Through some of their lyrics they propose a kind of progressive politics that underscores the importance of equality and anti-discrimination based on ethnic, cultural, gender and class positions.

\section{Los Tigres del where?}

Formed by the brothers Jorge, Hernán, Eduardo, and Luis Hernández, and their cousin Oscar Lara, in the late 1960s, Los Tigres del Norte started playing at weddings and social gatherings in the town of Rosa Morada in Sinaloa State, Mexico, in order to make money after their father had an accident. In 1968, after playing in Mexicali, Baja California, Los Tigres travelled to San José, California, where, it is popularly claimed, a promoter hired them to play at either a dieciséis de Septiembre or a cinco de mayo party. ${ }^{2}$ It is said that Los Tigres adopted their name because immigration officials called them "little tigers" due to their young age, ranging from 10 to 17 years in 1968 (Burr 1999: 201; “Biography”, par. 1-5; Ramírez Pimienta and Pimienta 2004: 43).

Los Tigres del Norte were eventually "discovered" by the Englishman Art Walker, also known as Arturo Caminante, who produced their three first albums through his company Fama Records (Wald 2001: 14; Ramírez Pimienta and Pimienta 2004: 44). The band released a few records that mixed cumbia, ranchera and bolero styles. However, when Walker and Jorge Hernández went to Los Angeles looking for new

\footnotetext{
${ }^{2}$ Dieciséis de Septiembre or September $16^{\text {th }}$ is the day each year when Mexican Independence from Spain is celebrated. The War of Independence began on the night of September $15^{\text {th }}, 1810$ in Dolores, Guanajuato and is also known as La noche del grito. Cinco de mayo (May $5^{\text {th }}$ ) celebrations commemorate the battle of Puebla, the defeat of Napoleon III's French army at the hands of the Mexican army in 1862.
} 
material they heard a mariachi singer called Joe Flores singing "Contrabando y traición" ("Contraband and Treason") (Wald 2001: 15). After a few attempts at cutting and recutting the song, they finally released an album, Contrabando y traición $(1971 ; 1995$ CD release), characterized by the Hernández brothers' harmonies and nasal sound (Wald 2001: 15). Los Tigres mainly sing corridos, but they also play a mix of cumbias and slow tempo rhythms, all driven by the powerful northern Mexican accordion sound.

Los Tigres del Norte are without a doubt the most famous and popular band in contemporary Mexico (Wald 2001: 2). The group has released more than 55 albums, sold more than 32 million copies, and (in the U.S.A.) received 12 Grammy nominations, winning in 1987 for the album América sin fronteras (1986) ("Biography" Telepolis, par. 14). ${ }^{3}$ They packed the Zócalo (Mexico City's main square) in 1999, where some 150,000 fans gathered to see the band (Wald 2001: 1). In addition to their success in Mexico, and among Mexican-origin and Central American communities in the U.S.A., people throughout the Spanish-speaking world have become familiar with the music of Los Tigres del Norte.

The band won best album in Premios Lo Nuestro in 1997 for Unidos para siempre and, in 1999 won the Premio Lo Nuestro a la excelencia, an award that acknowledged Los Tigres del Norte as one of the most important musical groups in the Spanish-speaking world. They have also been nominated many times for best album in the category of Mexican regional music and best Mexican band. ${ }^{4}$ In addition, they won the 2006 Latin Grammy's best "Norteño Album" prize for Historias que contar (2006), after previously winning Latin Grammy for "Best Norteño Performance" for Herencia de familia (1999) at the first Annual Latin Grammy Awards.

Nevertheless, while Los Tigres del Norte have become extremely sucessful in the U.S. they are arguably still considered an alternative band for their use of Spanish language

\footnotetext{
${ }^{3}$ Steven Loza (1993) points out that in 1983 "The National Academy of Recordings Arts and Sciences expanded its Latin category for the Grammy Awards" to include a Mexican American category, alongside Latin pop and tropical (115).

${ }^{4}$ Premios Lo Nuestro was inaugurated in 1989, and is an annual Spanish language award show on the Spanish language television network Univisión that celebrates Latino/a and Spanish-speaking popular music and awards prizes in a range of categories, from best band and song, to long trajectory and influence. The prizes have also been updated to acknowledge genres such as ranchera and tropical, to the best of rock and Urbana, a mix of hip hop and other Latin rhythms ("Premios Lo Nuestro a la musica Latina. Historia," last accessed 10/08/2005).
} 
and appeal to Spanish speaking populations.

In the last year, Los Tigres del Norte released the album Detalles y Emociones (2007) (Details and Emotions) which continues to make them a voice of the migrant communities. The album contains the song El muro (The Wall) which is a critique to the proposal of a wall to be constructed between Mexico and the U.S.A. (Detalles $y$ emociones, CD 2007).

In 2007, Los Tigres del Norte also appeared in the film Bajo la misma luna (Under the Same Moon) directed by Patricia Riggen which was very well received in the 2007 Sundance Film Festival. The film narrates the story of a mother and son relationship across the Mexican-American border.

\section{"We sing about the issues concerning our people"}

As mentioned before Los Tigres del Norte use popular music as a tool to express their community's experience. This experience has been, historically, one of subjugation and discrimination. In this paper, I will explore three themes found in some of Los Tigres del Norte lyrics, which exemplify their importance as community spokespeople and grass roots activists.

One of the characteristics found in their music is that, Los Tigres del norte continue the corrido tradition as a way of narrating their community's story and struggles.

Popular music, and in particular corridos, has been of great importance in the formation of a Mexican American community, recording events that have affected the lived experience of these communities. Events such as the Mexican American war of 18461848, immigration flows resulting from the Mexican Revolution in 1910 , and the $20^{\text {th }}$ century's huge migration of workers, have resulted in a significant increase in the number of Mexicans making the U.S.A. their home. Many of these events have been recorded in the corrido form.

George Lipsitz argues that the Mexican immigrant and Chicano/a communities have used popular music such as corridos in order to speak of their realities and experiences 
(1994: 16-17), illustrating Mario Arturo Ramos's (2002) point that the corrido is a popular or subaltern form of expression.

Indeed, the idea of the corrido genre as an alternative form of expression is the key to a canonical work in Chicano/a Studies, With a Pistol in his Hand (1958): In this book Americo Paredes notes that " [people from the borderlands] committed their daily affairs and their history to the ballad [or corrido] form" (15). Los Tigres del Norte highlight the importance of corridos as a tool for community expression in the song "El corrido" (1991 CD release):

Voz de nuestra gente, grito reprimido, un canto valiente.

Eso es el corrido

Voz del oprimido. Un retrato hablado.

Calificativo y hasta exagerado.

Tribuna que ha sido del pueblo juzgado.

Ese es el corrido que me han enseñado.

Pueblo que su historia

lee en un cancionero.

[Voice of our people, a repressed shout, brave song that is the corrido.

Voice of the oppressed.

A spoken portrait qualifying and even exaggerated.

A platform used by the [mis]judged people.

That is the corrido that they have taught me.

A people whose history reads in a songbook.]

Traditionally, corridos have served as a form for narrating the Mexican experience, and they have also been used to discuss and portray the tensions between Mexicans and European-Americans. Los Tigres del Norte's song "America" updates this tension to the relationship between the Mexican and Mexican American populations in the U.S.A. and their relation to the dominant national discourse that does not acknowledge them as real “Americans." Los Tigres del Norte question the idea that the U.S.A. is a Protestant and monolingual country:

Si él que nace en Europa es europeo, 
y él que nace en Africa, africano.

He nacido en América [the continent]

y no veo porque yo no he de ser americano.

Porque América es todo el continente

y el que nace aquí es americano.

[If he who is born in Europe is European

and he who is born in Africa, African.

I was born in America

and I do not see why I should not be "American"

because America is all the continent

and he who is born here is American.]

\section{Cruzando Fronteras: Undocumented crossings}

Thus, in their music, Los Tigres del Norte counter the dominant discourses of nation and nationality in the U.S.A. They also make a comment on the status of other migrant groups by speaking of shared social realities and similar experiences within U.S. national territory. For example, in the corrido "Tres veces mojado" ("Three Times a Wetback" 1991, 2000 CD), Los Tigres del Norte speak of the plight of Central American undocumented immigrants who have to cross the Guatemalan, southern and northern Mexican borders:

Cuando me vine de mi tierra el Salvador con la intención de llegar a Estados Unidos sabía que necesitaría más que valor, sabía que a lo mejor me quedaba en el camino. Son tres frontreras las que tuve que cruzar. Por tres países anduve indocumentado. Tres veces tuve yo la vida que arriesgar por eso me dicen que soy tres veces mojado. En Guatemala y México cuando crucé dos veces me salvé me hicieran prisionero. El mismo idioma y el color reflexioné: ¿cómo es posible que me llamen extranjero?

[When I came from my country El Salvador with the intention of getting to the United States, I knew that I would need more than courage I knew I may stay on the road. There are three frontiers that I had to cross. Around three countries I travelled without documents. Three times I had to risk my life For this they tell me that I am three times wetback. In Guatemala and Mexico when I crossed, twice I escaped from being taken prisoner. 
The same language and colour, I thought, How is it possible that they call me foreigner?]

Los Tigres del Norte narrate not only the traumatic experiences of Mexican nationals crossing the border into the U.S. without documents, but also engage with the struggles of Central Americans entering both Mexico and the U.S., thus presenting to audiences a generalized experience of undocumented immigration.

\section{Los hijos de Hernández}

In "Los hijos de Hernández” (“Hernandez’s Children” 1986-88, 1991 CD), Los Tigres speak of the negative stereotypes applied to Mexican immigrants. While it is obvious in the song that the narrator is a resident of the U.S.A., the migration officer assumes the man is coming to work and to take jobs from U.S. citizens. Nevertheless, the narrator asserts his place in the U.S. by acknowledging not only the input of the Mexican and Latin American immigrant work force, but also the little mentioned fact that his children are fighting for the U.S.A.:

le dije muy enojado:

"eso que tu haz murmurado

tiene mucho de verdad,

los latinoamericanos a muchos americanos

le han quitado su lugar.

Sí, muy duro trabajamos tampoco

no nos rajamos si la vida hay que arriesgar

en los campos de combate

nos han echado adelante porque sabemos pelear."

[I said angrily:

"that what you have whispered

has a lot of truth to it.

The Latin Americans

have taken the place of many Americans.

Yes, we work very hard and

we don't back down

when in the battlefields

they have sent us to the front

because we know how to fight"]

The song foregrounds the hypocrisy of a nation that, having subjugated these communities along race, ethnicity and class lines, conveniently ignores the soldiers' ethnic and racial background when they are needed in the army. In this way, it is 
arguable that Los Tigres del Norte continue the Chicano/a movement fight for human rights and equality. Los Tigres del Norte claim a place for Mexican migrants and Chicanos/as as a viable and productive constituency within the U.S.A.

\section{¡Tambien las mujeres pueden!}

The last point I want to highlight is that, while not explicitly influenced by the feminist movement, Los Tigres often challenge the subjugated roles given to female characters. They do so by singing corridos in which the main role - traditionally male-is occupied by a woman. For example, in the corrido "La reina del sur" ("The Queen of the South" 2002) the main character is Teresa Mendoza, a woman who becomes a drug tsar. They also sing of empowered women as brave as their male drug-trafficking counterparts, such as Camelia la Tejana and the female characters in the corrido "También las mujeres pueden” (“Women can Too!” 1997).

Songs such as "Contrabando y traición" (“Contraband and Treason" 1973-76?) and "La reina del sur" (“The Queen of the South" 2002) engage with smuggling, in this case of drugs, but the main characters are strong women who, due to unforeseen circumstances, find themselves doing the same things as the male characters in the narcocorrido. A good example is Teresa Mendoza in "La reina del sur" ("The Queen of the South" 2002):

Supo aprender el acento que se usa por todo España.

Demostró su jerarquía como la más noble dama.

A muchos los sorprendio Teresa la mexicana.

Era la reina del sur

allá en su tierra natal.

Teresa la mexicana,

del otro lado del mar.

Una mujer muy valiente,

que no la van a olvidar.

Un día desaparecio, Teresa la mexicana

Dicen que que esta en la prisión, otros que vive en Italia

En California o Miami, de la unión Americana.

[She learned the accent that is used in Spain.

She showed her chain of command like a noble woman.

Many people were surprised by Teresa the Mexican.

She was the queen of the south,

in her native land. Teresa the Mexican, 
on the other side of the sea.

A very brave woman, who no one is going to forget.

One day Teresa the Mexican disappeared.

Some say that she is in prison, other that she lives in Italy, in California or Miami in the American Union]

In this corrido, Teresa Mendoza is a woman who finds herself running away from both drug-trafficking cartels and the police, yet becomes a cartel leader. In traditional corridos, the position of power that Teresa enjoys would be taken by a male character. In this way, Los Tigres depart from convention, using instead of male characters the image of a woman who can achieve success and respect, both in Mexico and abroad, in a very violent environment. The same is the case for corridos such as "Tambien las mujeres pueden" (“Women Can Too!" 1997), in which Los Tigres narrate a violent encounter between Mexican and Colombian female drug-traffickers, thus departing, again, from traditional corridos in which the main character or hero is male.

\section{Las mujeres de Juárez}

Los Tigres del Norte narrate events that have affected the Mexican population dispersed across borders. Since 2004, Los Tigres del Norte have been outspoken about the murders of women in the border town of Cuidad Juaréz, Chihuahua, and have sung about violence against women, as exemplified by their corrido "Las mujeres de Juaréz" ("The Women of Juárez" 2004). Over the past few years a great number of dead women have been found in the outskirts of Ciudad Juárez's shantytowns. These women are maquíladora workers who decided to leave their towns in the interior of Mexico in order to make money as cheap factory labour in border assembly plants. In a newspaper interview, Los Tigres del Norte's lead singer reflects on the nature of the band's music:

Los Tigres del Norte siempre hablamos de situaciones verídicas que afectan al pueblo. Decidimos hacer este tema porque siempre nos preguntaban que cuándo haríamos un corrido sobre las muertas de Juárez" [Los Tigres del Norte always talk about the real conditions affecting people. We decided to do this song because we were always asked when would we do a corrido about the dead women in Juárez] (Castañeda 2004: par. 13).

The corrido "Las mujeres de Juárez" ("The Women of Juarez" 2004) shows the preoccupations of Los Tigres del Norte wih this problem: "Ya hay varias miles de muertas en panteones clandestinos. Muchas desaparecidas que me resisto a creer. Es el 
reclamo del pueblo que lo averigüe la ley" [There are several thousand dead women, in secret cemeteries. So many women have disappeared, it is hard to believe. These people demand that the law must investigate].

The killing of women in Juaréz is, in part, a reflection of the subjugation of women in Mexican society. Apart from telling of the tragic deaths in Juaréz, Los Tigres inform the wider audience about the events that are taking place and call for action:

Llantos, lamentos y rezos, se escuchan en el lugar, de las madres angustiadas, que al cielo imploran piedad, que les devuelvan los restos, y poderlos sepultar.

El gran policía del mundo también nos quiso ayudar pero las leyes aztecas no quisieron aceptar, tal vez no les convenía que eso se llegue a aclarar.

[Crying, laments and prayers, are heard in this place, of distressed mothers, who implore heaven that the remains be returned to them, so they may bury them.

The great police of the world also wanted to help us but theAztec laws did not want to accept, perhaps because it was convenient that it didn't get cleared up]

It is important to note that in the same song, Los Tigres del Norte engage with the notion of machismo, the dominant Mexican gender discourse that places women in a subjugated role to men: ${ }^{5}$

Vergonzosos comentarios,

\footnotetext{
${ }^{5}$ Machismo is a term that designates the codes, behaviours and ideals by which masculinity is said to be structured in Latin American and Latino/a societies (Allatson 2007: 146).
} 
se escuchan por todo el mundo, la respuesta es muy sencilla, Juárez sabe la verdad, ¿ya se nos quitó lo macho? ¿o nos falta dignidad?

[Shameful comments, are heard throughout the world, the answer is very simple, Juaréz knows the truth, have we lost the macho quality? Or do we lack dignity?]

Rather than critiquing machismo and the patriarchal order in "Las mujeres de Juaréz" ("The Women of Juarez" 2004), Los Tigres del Norte address the fact that the traditional machista codes of honour and masculinity have collapsed, as has the idea that a real macho would never hurt "his" woman, but would instead take care of her.

Nevertheless, for Los Tigres del Norte, rather than blaming the women for the abuse they have endured, they note that part of being a man ought to ensure that the killing and violence against women is stopped and that the men responsible for these events be brought to trial. While it might be said that Los Tigres continue to propagate the idea that women need men to protect them, they do bring to light the violence committed against women. This move effectively works as grass-roots activism when Los Tigres del Norte say:

es momento ciudadanos, de cumplir nuestro deber, si la ley no lo resuelve, lo debemos resolver, castigando a los cobardes que ultrajan a la mujer.

[it is time citizens, to comply with our duties, if the law does not resolve it, we should resolve it, punishing the cowards who abuse women]

In conclusion, using the corrido form Los Tigres continue a Mexican tradition of using popular music as a way of expressing community issues. They also update this tradition to narrate important events affecting the everyday Mexican, Mexican American and 
Mexican migrant experience. Thus, Los Tigres del Norte must be regarded as grass roots activist who exemplify the use of popular music as an alternative form of social activism.

\section{Bibliography}

Allatson, P. (2007) Key Terms in Latino/a Cultural and Literary Studies. Malden, MA, and Oxford: Blackwell Publishing.

Burr, R. (1999) The Billboard Guide to Tejano and Regional Mexican Music. NewYork: Billboard Books.

Lipsitz, G. (1994) Dangerous Crossroads. Popular Music, Postmodernism and the Poetics of Place. London: Verso.

Los Tigres del Norte (199?) Page no longer available. Last accessed 1 May 2006. $<$ http://club.telepolis.com.tigresnorte/>

Paredes, A. (1958) With His Pistol in His Hand. Austin: University of Texas Press.

Ramírez P, J. Carlos, and J. Pimienta. (2004) ‘ ¿Todavía es el corrido la voz de nuestra gente?: Una entrevista con Enrique Franco.' Studies in Latin American Popular Culture 23 (2004): 43-54.

Ramos, M. A. (2002) Cien corridos mexicanos. Alma de la canción mexicana. México: Océano.

Wald, E. 2002. Narcocorrido. A Journey into the Music of Drugs, Guns, and Guerillas. New York: Harper Collins. 